\title{
Antihypertensive drug telmisartan inhibits cell proliferation of gastrointestinal stromal tumor cells in vitro
}

\author{
HIDEKI KOBARA ${ }^{1}$, SHINTARO FUJIHARA ${ }^{1}$, HISAKAZU IWAMA ${ }^{2}$, TAKANORI MATSUI $^{1}$, AYAKO FUJIMORI ${ }^{1}$, \\ TAIGA CHIYO $^{1}$, SHI TINGTING ${ }^{1}$, NOBUYA KOBAYASHI ${ }^{1}$, NORIKO NISHIYAMA ${ }^{1}$, TATSUO YACHIDA ${ }^{1}$, \\ TOMOKO TADOKORO $^{1}$, KYOKO OURA ${ }^{1}$, JOJI TANI ${ }^{1}$, KOJI FUJITA ${ }^{1}$, TAKAKO NOMURA ${ }^{1}$, \\ HIROHITO YONEYAMA ${ }^{1}$, ASAHIRO MORISHITA ${ }^{1}$, KEIICHI OKANO $^{3}$, YASUYUKI SUZUKI ${ }^{3}$, \\ HIROHITO MORI $^{1}$ and TSUTOMU MASAKI ${ }^{1}$
}

${ }^{1}$ Department of Gastroenterology and Neurology; ${ }^{2}$ Life Science Research Center; ${ }^{3}$ Department of Gastroenterological Surgery, Faculty of Medicine, Kagawa University, Miki, Kita, Kagawa 761-0793, Japan

Received August 10, 2019; Accepted March 20, 2020

DOI: $10.3892 / \mathrm{mmr} .2020 .11144$

\begin{abstract}
Gastrointestinal stromal tumors (GISTs) are the most common mesenchymal tumors of the digestive tract. The angiotensin II type 1 receptor blockers, telmisartan and candesartan, are widely used antihypertensive drugs that inhibits cancer cell proliferation; however, its underlying mechanisms in mesenchymal tumors, including GIST, remains unknown. The present study aimed to investigate the effect of telmisartan on GIST-T1 cells and its underlying mechanism. Telmisartan and candesartan inhibited the proliferation of these cells by blocking the G0 to G1 cell cycle transition, which was accompanied by a decrease in cell cycle-related proteins such as cyclin D1. Furthermore, telmisartan exposure significantly altered microRNA expression in vitro. In conclusion, telmisartan suppressed human GIST cell proliferation by inducing cell cycle arrest in vitro.
\end{abstract}

\section{Introduction}

Gastrointestinal stromal tumors (GISTs) are the most common mesenchymal tumors of the digestive tract (1); the annual incidence is between $11-14.5$ per million people, and the prevalence is estimated to be 129 per million individuals (1). Moreover, a National Cancer Database reported

Correspondence to: Dr Hideki Kobara, Department of Gastroenterology and Neurology, Faculty of Medicine, Kagawa University, 1750-1 Ikenobe, Miki, Kita, Kagawa 761-0793, Japan E-mail: kobara@med.kagawa-u.ac.jp

Abbreviations: ARB, angiotensin II type 1 receptor blocker; AMPK, AMP-activated protein kinase; GIST, gastrointestinal stromal tumor; mTOR, mammalian target of rapamycin; PDGFRA, platelet-derived growth factor receptor- $\alpha$

Key words: gastrointestinal stromal tumor, telmisartan, cyclin, angiotensin II type 1 receptor blocker, apoptosis a cause-specific mortality rate of $14.0 \%$ and a 5-year survival rate of $\sim 82 \%$ (2). GISTs arise predominantly in the stomach but also occur in the small intestine, colon and rectum (3). It is considered a spindle or epithelioid cell neoplasm that expresses the mast/stem cell growth factor receptor Kit (KIT) protein and that has a KIT or platelet-derived growth factor receptor- $\alpha$ (PDGFRA) gene mutation (4,5). KIT and PDGFRA are receptor tyrosine kinases, and gain-of-function mutations of the KIT or PDGFRA gene serve central roles in GIST pathogenesis by activating KIT downstream signals such as the phosphoinositide 3-kinase/AKT/mTOR pathway (6).

Angiotensin II receptor blockers (ARBs) are widely used to treat chronic kidney disease, heart failure and hypertension (7). Previous studies have shown that angiotensin II is associated with cancer progression and that ARBs inhibit tumor growth by binding to the angiotensin II type 1 receptor (8-10), including in various common types of cancer cells such as breast (11), endometrial (12) and stomach (13) in vitro and in vivo. Furthermore, ARBs have been associated with reduced incidence and mortality rates in several types of cancer in patients with hypertension $(14,15)$. Among these ARBs, telmisartan was reported to inhibit proliferation of various types of cancer cells, including urological $(16,17)$ and colon (18) cancers, by inducing apoptosis.

AMP-activated protein kinase (AMPK) is an energy sensor and a major regulator of cellular energy homeostasis (19). It is hypothesized that AMPK activation inhibits the mTOR signaling pathway. Since ribosomal protein S6 kinase 1 (p70S6K) is downstream of mTOR, inhibition of mTOR inhibits its activation, thus leading to reduced protein synthesis, which is necessary for cancer cell growth $(20,21)$. Recent reports have demonstrated that telmisartan contributes to AMPK activation and regulation of the mTOR pathway in various types of cancers, and it induces a reduction in p70S6K activation, thus decreasing protein synthesis $(22,23)$. However, the mechanisms underlying the antiproliferative effects of telmisartan in GIST remains unclear.

In the present study, the antiproliferative effect of telmisartan and its mechanism of action were evaluated in GIST-T1 cells. It has previously been reported that microRNA (miRNA) 
signatures have a role in the antitumor effect of telmisartan in esophageal adenocarcinoma and hepatocellular carcinoma by modulating the cell cycle $(22,23)$. In the past 10 years, increasing evidence has indicated that miRNAs directly control cell cycle progression by targeting cell cycle regulators (24). Additionally, miRNAs indirectly control cell cycle progression by targeting signal transduction pathways in anticancer therapy $(22,23)$. In the present study it was hypothesized that unidentified miRNAs have a role in the effect of telmisartan treatment on GIST and may be targets for novel therapeutic options. The results revealed that telmisartan inhibited the proliferation of GIT-T1 cells and induced cell cycle arrest, as well as altering miRNA expression.

\section{Materials and methods}

Chemicals and antibodies. Telmisartan and valsartan were purchased from Tokyo Chemical Industry Co., Ltd. Irbesartan was purchased from Wako Pure Chemical Industries, Ltd. Candesartan was purchased from AdooQ BioScience. Telmisartan was prepared as a $10 \mathrm{mM}$ stock solution in dimethyl sulfoxide (DMSO). Valsartan, irbesartan and candesartan were prepared as $100 \mathrm{mM}$ stock solutions in DMSO. The stock solutions were stored at $-20^{\circ} \mathrm{C}$. The following materials were used: Cell Cycle Phase Determination kit (Cayman Chemical Company), Annexin V-FITC Early Apoptosis Detection kit (Cell Signaling Technology, Inc.), protease inhibitor cocktail (Pro-Prep, complete protease inhibitor mixture; Intron Biotechnology, Inc.) and Angiogenesis Antibody Array kits (R\&D Systems, Inc.).

Primary antibodies used for western blot analyses were obtained from the following sources. $\beta$-actin antibody was obtained from Sigma-Aldrich. Cyclin D1 and cyclin E antibodies were obtained from Thermo Fisher Scientific, Inc. Cdk6, Cdk2, Cdk4 and Rb antibodies were obtained from Santa Cruz Biotechnology, Inc. Phosphorylated (p)-Rb was purchased from BD Pharmingen (BD Bioscience). AMPK $\alpha$, p-AMPK $\alpha$ Thr172, mTOR, p-mTOR, p70S6K and p-p70S6K antibodies were purchased from Cell Signaling Technology, Inc. Horseradish peroxidase (HRP)-conjugated anti-mouse and anti-rabbit IgG secondary antibodies (Cell Signaling Technology, Inc.) were used.

Cell culture. The human GIST-T1 cell line was obtained from Cosmo Bio Co., Ltd. GIST-T1 cells were maintained at $37^{\circ} \mathrm{C}$ with $5 \% \mathrm{CO}_{2}$ in DMEM (Gibco; Thermo Fisher Scientific, Inc.) supplemented with $10 \%$ fetal bovine serum (FBS; FUJIFILM Wako Pure Chemical Corporation), $20 \mathrm{U} / \mathrm{ml}$ penicillin and $100 \mu \mathrm{g} / \mathrm{ml}$ streptomycin (Invitrogen; Thermo Fisher Scientific, Inc.).

Cell proliferation assay. Cell proliferation of GIST-T1 cells was assayed using CCK-8 (Dojindo Molecular Technologies, Inc), according to the manufacturer's instructions. Briefly, $5 \times 10^{3}$ cells of each experiment group were equally seeded on 96-well plates and cultured in $100 \mu \mathrm{l}$ DMEM (Gibco; Thermo Fisher Scientific, Inc.) supplemented with $10 \%$ FBS for $24 \mathrm{~h}$. Subsequently, 0, 1, 10 or $100 \mu \mathrm{m}$ ARBs (telmisartan, candesartan, valsartan or irbesartan) or vehicle were added to each well, and the cells were cultured for an additional $48 \mathrm{~h}$. CCK-8 reagent $(10 \mu \mathrm{l})$ was added to each well, and the plates were incubated at $37^{\circ} \mathrm{C}$ for $3 \mathrm{~h}$, and the absorbance was measured at $450 \mathrm{~nm}$ using a microplate reader (Thermo Fisher Scientific, Inc.).

Cell cycle and apoptosis analyses. Cell cycle profiles were analyzed after telmisartan treatment to assess growth inhibition. GIST-T1 cells $\left(1 \times 10^{6}\right.$ cells in a $100-\mathrm{mm}$ diameter dish) were treated with or without $100 \mu \mathrm{m}$ telmisartan for 24-48 h. Cell cycle progression was analyzed by measuring the amount of propidium iodide (PI)-labeled DNA in ethanol-fixed cells. The fixed cells were washed with PBS and then stored at $-20^{\circ} \mathrm{C}$ for flow cytometry analysis. On the day of analysis, the cells were washed with cold PBS, suspended in $100 \mu 1$ of PBS with $10 \mu \mathrm{l}$ of RNase $\mathrm{A}(250 \mu \mathrm{g} / \mathrm{ml})$ and incubated at $4^{\circ} \mathrm{C}$ for $30 \mathrm{~min}$. A $110-\mu 1$ aliquot of PI $(100 \mu \mathrm{g} / \mathrm{ml})$ was added to each suspension, and the cells were incubated at $4^{\circ} \mathrm{C}$ for at least $30 \mathrm{~min}$ prior to analysis. For apoptosis analysis, cells were stained with FITC-conjugated Annexin V and PI (Annexin V-FITC Early Apoptosis Detection kit; Cell Signaling Technology, Inc.), then incubated for $10 \mathrm{~min}$ on ice in the dark. Tumor cells were stained for 24 or $48 \mathrm{~h}$, according to the manufacturer's instructions. Flow cytometry was performed using a Cytomics FC500 flow cytometer (Beckman Coulter, Inc.). The percentages of cells were determined using Kaluza Analysis v2.1 software (Beckman Coulter, Inc.). All experiments were performed in triplicate.

Western blotting. Western blotting was performed according to a previously described method (22). The cells were lysed in a protease inhibitor cocktail ('complete' protease inhibitor mixture; iNtRON Biotechnology, Inc.) on ice for $20 \mathrm{~min}$. Protein concentrations were measured using a NanoDrop 2000 fluorospectrometer (Thermo Fisher Scientific, Inc.). Protein aliquots (1-10 $\mu \mathrm{g})$ were resuspended in sample buffer and separated on $10 \%$ Tris-glycine gradient gels via SDS-PAGE (25). After blocking in 5\% dry skim milk in TBS with $0.05 \%$ Tween-20 (TBST) for $1 \mathrm{~h}$ at room temperature, the membranes were incubated with primary antibodies against cyclin D1 (cat. no AHF0082; 1:2,000), cyclin E (cat. no. MA5-14336; 1:1,000), cdk6 (cat. no. sc-177; 1:5,000), cdk2 (cat. no. sc-163; 1:5,000), cdk4 (cat. no. sc-749; 1:1,000), Rb (cat. no. sc-50; 1:4,000), p-Rb (cat. no. 558385; 1:1,000), AMPK $\alpha$ (cat. no. 5832; $1: 5,000)$, p-AMPK $\alpha$ (cat. no. 2535; 1:1,000), mTOR (cat. no. $2983 ; 1: 1,000$ ), p-mTOR (cat. no. 5536; 1:1,000), p70S6K (cat. no. 2708; 1:1,000), p-p70S6K (cat. no. 9205; 1:1,000) and $\beta$-actin (cat. no. A5441; 1:5,000) overnight at $4^{\circ} \mathrm{C}$, followed by HRP-conjugated secondary antibodies (cat. nos. 7074 and $7076 ; 1: 2,000)$ in $5 \%$ dry skimmed milk in TBS for $1 \mathrm{~h}$ at room temperature (26). The proteins were visualized on X-ray film using an Enhanced Chemiluminescence Detection system (PerkinElmer, Inc.). Band intensities were semi-quantified using ImageJ software v1.52q (National Institutes of Health) and normalized to $\beta$-actin.

Analysis of angiogenesis-related protein profiles using an antibody array. A Human Angiogenesis Antibody Array (R\&D Systems, Inc.) was used according to the manufacturer's protocol. This method is a dot-based assay that enables the detection and comparison of 55 angiogenesis-specific cytokines. Each array membrane was exposed to X-ray film using a chemiluminescence detection system (PerkinElmer, Inc.). 
miRNA array. miRNA array analysis was performed as described in a previous study (17). Total RNA was extracted from the cancer cell lines using a miRNeasy Mini kit (Qiagen $\mathrm{GmbH}$ ), according to the manufacturer's instructions. RNA samples typically exhibited $\mathrm{A}_{260 / 280}$ ratios between 1.9 and 2.1, as determined using an Agilent 2100 Bioanalyzer (Agilent Technologies, Inc.). After performing RNA measurements with an RNA 6000 Nano kit (Agilent Technologies, Inc.), the samples were labeled using a miRCURY Hy3/Hy5 Power Labeling kit and subsequently hybridized to a human miRNA Oligo chip (v.21.0; Toray Industries, Inc.). The chips were scanned with a 3D-Gene ${ }^{\circledR}$ Scanner 3000 (Toray Industries, Inc.), and the results were analyzed using 3D-Gene Extraction software, v1.2 (Toray Industries, Inc.). Differences in miRNA expression between the telmisartan-treated and untreated control samples were assessed using GeneSpring GX v10.0 (Agilent Technologies, Inc.). Quantile normalization was performed on the raw data that were above the background level. Differentially expressed miRNAs were determined by the Mann-Whitney U test. The false discovery rate was computed using the Benjamini-Hochberg method for multiple testing (27). Hierarchical clustering was performed using the furthest-neighbor method with the absolute uncentered Pearson's correlation coefficient as a metric. A heat map was produced with the relative expression intensity for each miRNA, in which the $\log 2$ of the intensity was median-centered for each row.

Statistical analyses. In vitro experiments were performed in triplicate and results are expressed as the mean \pm SD. All statistical analyses were performed using GraphPad Prism 6 software (GraphPad Software, Inc.). Non-parametric Wilcoxon/Man-Whitney U test was utilized to examine statistical significance between the two groups, and Kruskal-Wallis test followed by Dunns post-hoc test was performed to analyze multiple comparisons. $\mathrm{P}<0.05$ was considered statistically significant.

\section{Results}

Telmisartan inhibits human GIST cell proliferation and viability by inducing cell cycle arrest at G0/G1 phase. GIST-T1 cells were treated with $0,1,10$ or $100 \mu \mathrm{m}$ of the ARBs (telmisartan, candesartan, irbesartan or valsartan) for $48 \mathrm{~h}$. Telmisartan and candesartan inhibited the proliferation of GIST-T1 cells (Fig. 1). No other ARBs affected GIST-T1 cell viability. These results revealed that telmisartan and candesartan inhibited cell proliferation dose- and time-dependently in the GIST-1 cell lines (Fig. 1).

The effects of telmisartan on the cell cycle in GIST-T1 cells was further investigated by flow cytometry. When GIST-T1 cells were incubated with $100 \mu \mathrm{m}$ of telmisartan, the number of cells decreased in $\mathrm{S}$ and $\mathrm{G} 2 / \mathrm{M}$ phases and increased in $\mathrm{G} 0 / \mathrm{G} 1$ phases for $48 \mathrm{~h}$ compared with the control group (Fig. 2A and B). To investigate how telmisartan influences GIST-T1 cell growth, apoptosis was analyzed. The apoptotic effects of 0 and $100 \mu \mathrm{m}$ telmisartan were measured by flow cytometric analysis of annexin V-FITC/PI staining. According to previous studies $(18,28), 100 \mu \mathrm{m}$ telmisartan induces apoptosis at first $24 \mathrm{~h}$, but not for $48 \mathrm{~h}$ at treatment. As shown in
Fig. 2C, telmisartan did not induce a significant change in the proportion of apoptotic GIST-T1 cells at $24 \mathrm{~h}$ post-treatment. Furthermore, the expression of cyclin D1 decreased in GIST-T1 cells after treatment with telmisartan compared with the control group (Fig. 3). There were no notable changes in the protein expression levels of cyclin E, Cdk2, Cdk4, Cdk6, p-Rb and $\mathrm{Rb}$ in telmisartan-treated GIST-T1 cells. These results suggested that telmisartan may inhibit cell cycle progression from $\mathrm{G} 0 / \mathrm{G} 1$ to $\mathrm{S}$ phase by decreasing the expression levels of cyclin D1.

Telmisartan induces AMPK phosphorylation but does not suppress the AMPKa/mTOR pathway in GIST-T1 cells. To examine the mechanism of telmisartan-induced cell cycle arrest, AMPK/mTOR signaling was studied. Telmisartan significantly induced phosphorylation of AMPK $\alpha$ in GIST-T1 cells compared with the control group, and this activation lasted for at least $48 \mathrm{~h}$ (Fig. 4). Conversely, p-mTOR and p-p70S6K protein levels did not change in the GIST-T1 cells following treatment with telmisartan (Fig. 4). These results suggest that telmisartan activated AMPK $\alpha$, but did not suppress mTOR in GIST-T1 cells.

Association between telmisartan and angiogenesis of GIST-TI cells. To identify angiogenic factors that may be affected by telmisartan, a human angiogenesis array kit was applied to GIST-T1 cells (Fig. 5A). The 55 angiogenesis-related proteins on the antibody array remained unchanged after telmisartan treatment (Fig. 5B).

miRNA expression signatures are different in telmisartan-treated and untreated GIST-1 cells. A miRNA microarray was used to examine the expression levels of 2,555 miRNAs in GIST-T1 cells treated with or without $100 \mu \mathrm{m}$ telmisartan. After normalization and removing miRNAs with missing values, 14 miRNAs were identified to be significantly differentially expressed. Of them, 7 were found to be significantly upregulated and the other 7 were downregulated (Fig. 6; Table I).

\section{Discussion}

The present study focused on the antiproliferative effects of telmisartan in GIST cells. According to previous studies, telmisartan inhibits cell proliferation (6-8) and tumor growth (9-11) in vitro and in vivo. Moreover, epidemiologic studies have revealed that the use of ARBs may increase the risk of cancer (29), whereas observational studies have shown that ARBs may reduce cancer incidence and mortality $(30,14)$. However, the antiproliferative effects of telmisartan on GIST cells remains unknown. To the best of our knowledge, the present study is the first to demonstrate that telmisartan has antiproliferative effects on human GIST-T1 cells in vitro.

Cyclin D1 and Cdks are important regulatory proteins that promote the progression of the cell cycle during the crucial restriction point at the G1/S phase transition (31). In the present study flow cytometric analyses revealed that telmisartan induced cell cycle arrest in the G0/G1 phase. Additionally, the level of the cell cycle regulatory protein cyclin D1 was significantly reduced. Cyclin/Cdk complexes are activated at 

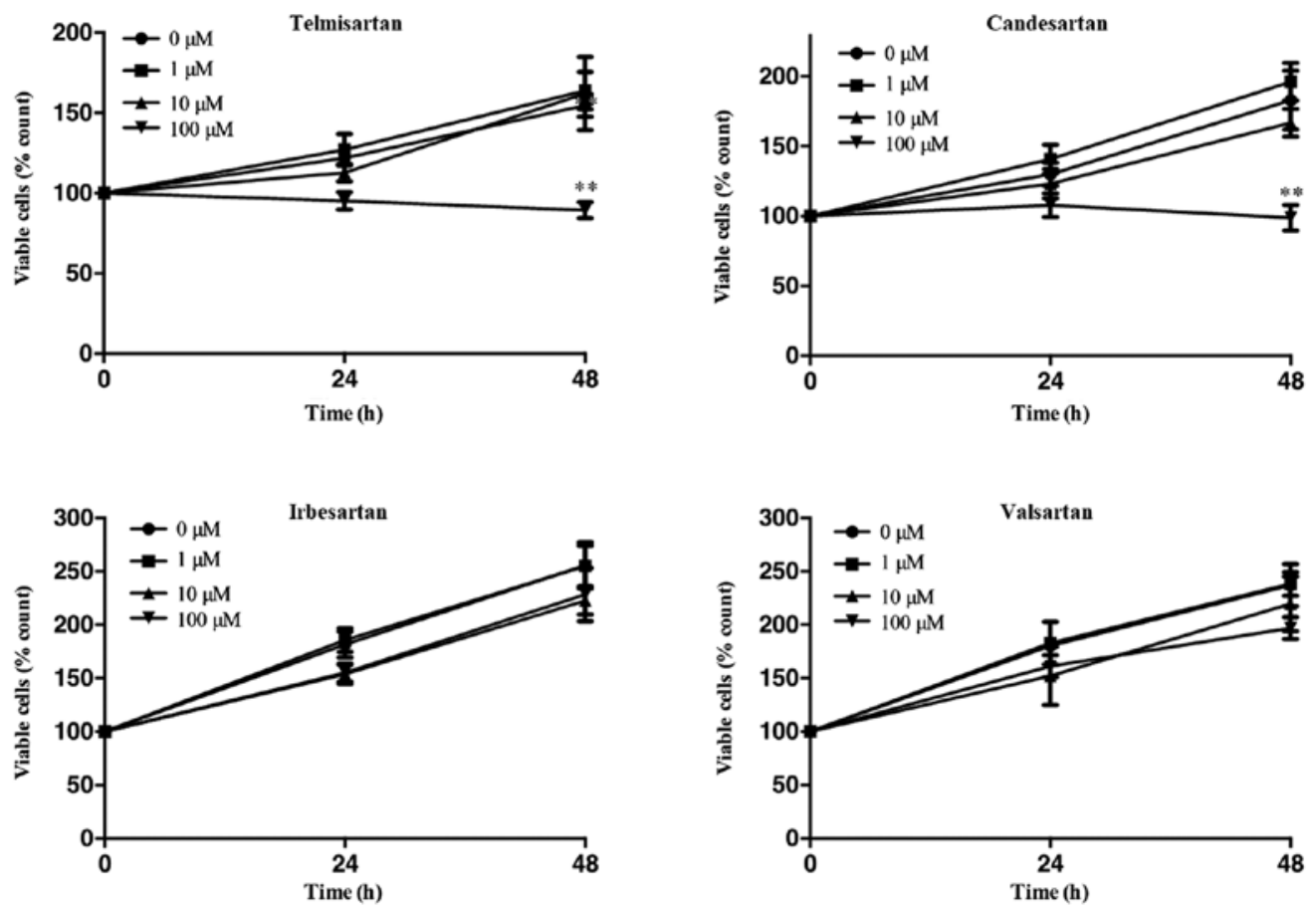

Figure 1. Antiproliferative effects of four angiotensin II receptor blockers (telmisartan, candesartan, losartan and valsartan) in GIST-T1 cells. Telmisartan and candesartan suppressed cell proliferation of GIST-T1 cells. The viability of the telmisartan-treated cells differed significantly. ${ }^{* *} \mathrm{P}<0.01$ vs. $0 \mu \mathrm{m}$ group. GIST, gastrointestinal stromal tumor.

A
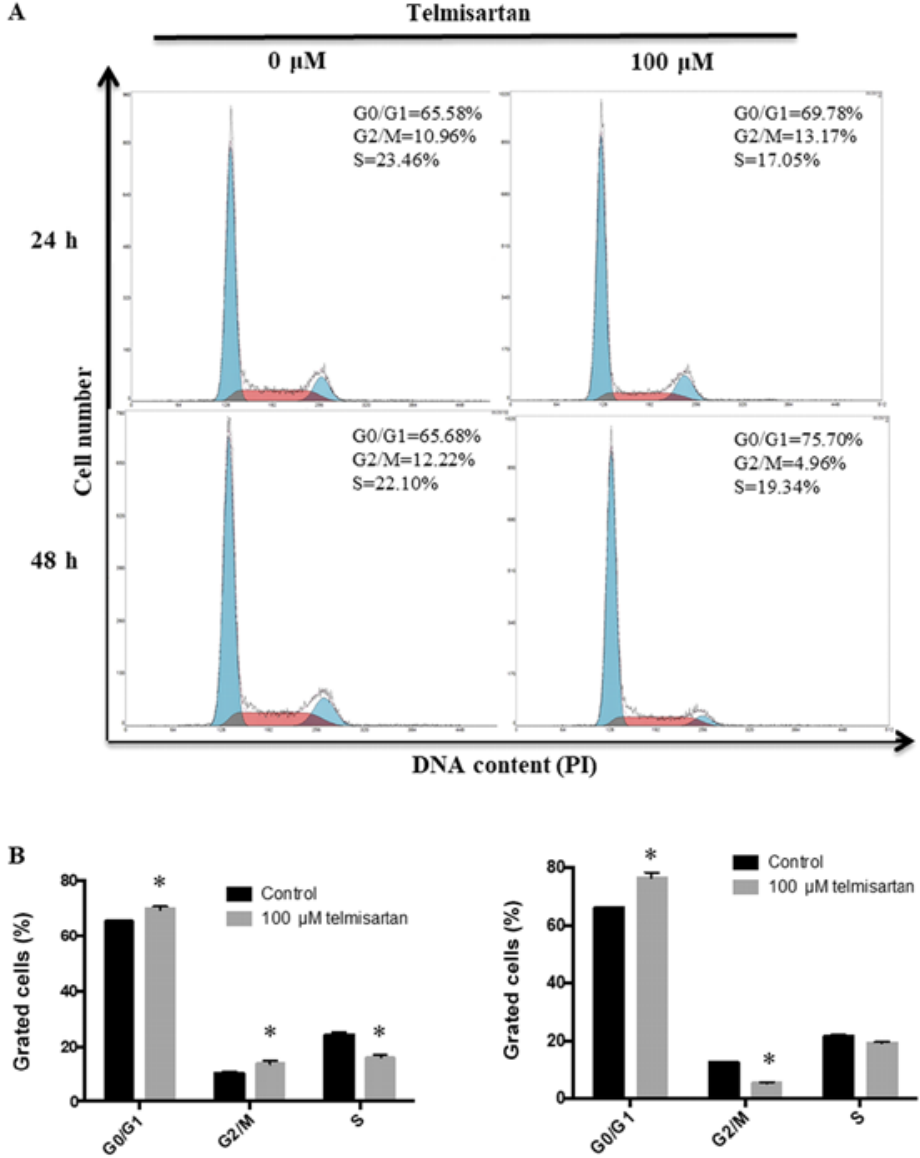

$24 \mathrm{~h}$

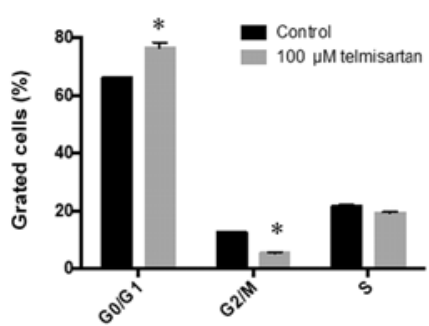

$48 \mathrm{~h}$
C
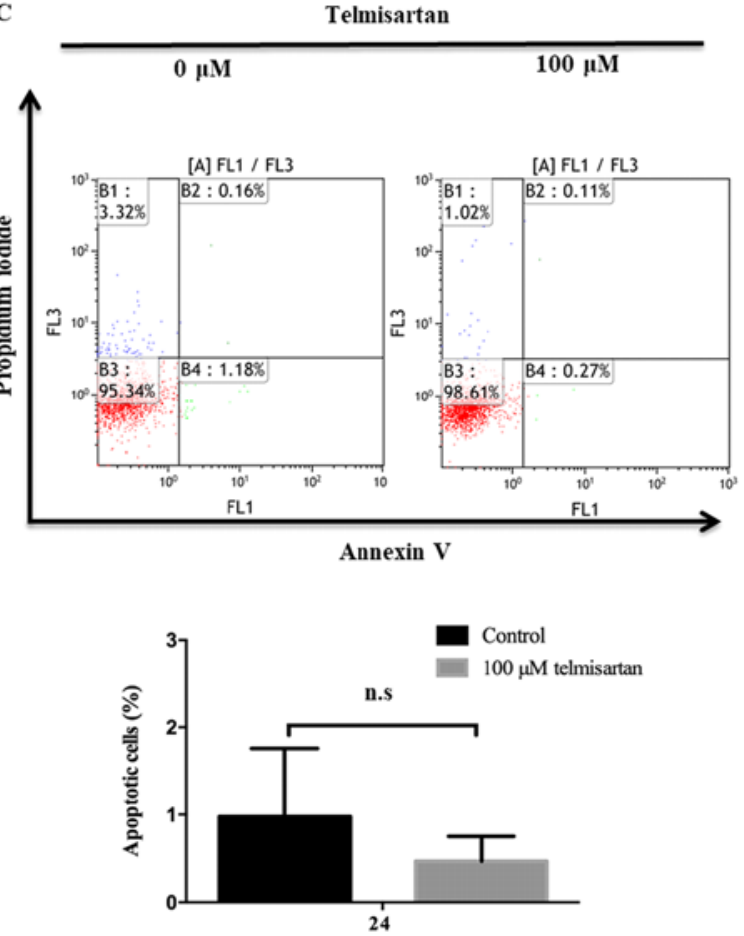

Incubation time (h)

Figure 2. Telmisartan induces G0/G1 cell cycle arrest in GIST-T1 cells (A) Representative flow cytometry results showing the distribution of GIST-T1 cells in $\mathrm{G} 0 / \mathrm{G} 1, \mathrm{~S}$ and $\mathrm{G} 2 / \mathrm{M}$ phases following treatment with telmisartan $(100 \mu \mathrm{m})$ or without at 24 and $48 \mathrm{~h}$. (B) Histograms showing the percentage of GIST-T1 cells in G0/G1, S and G2/M phases. "P<0.05 vs. control. (C) Telmisartan did not induce apoptosis in the GIST-T1 cells. GIST, gastrointestinal stromal tumor; n.s., not significant. 


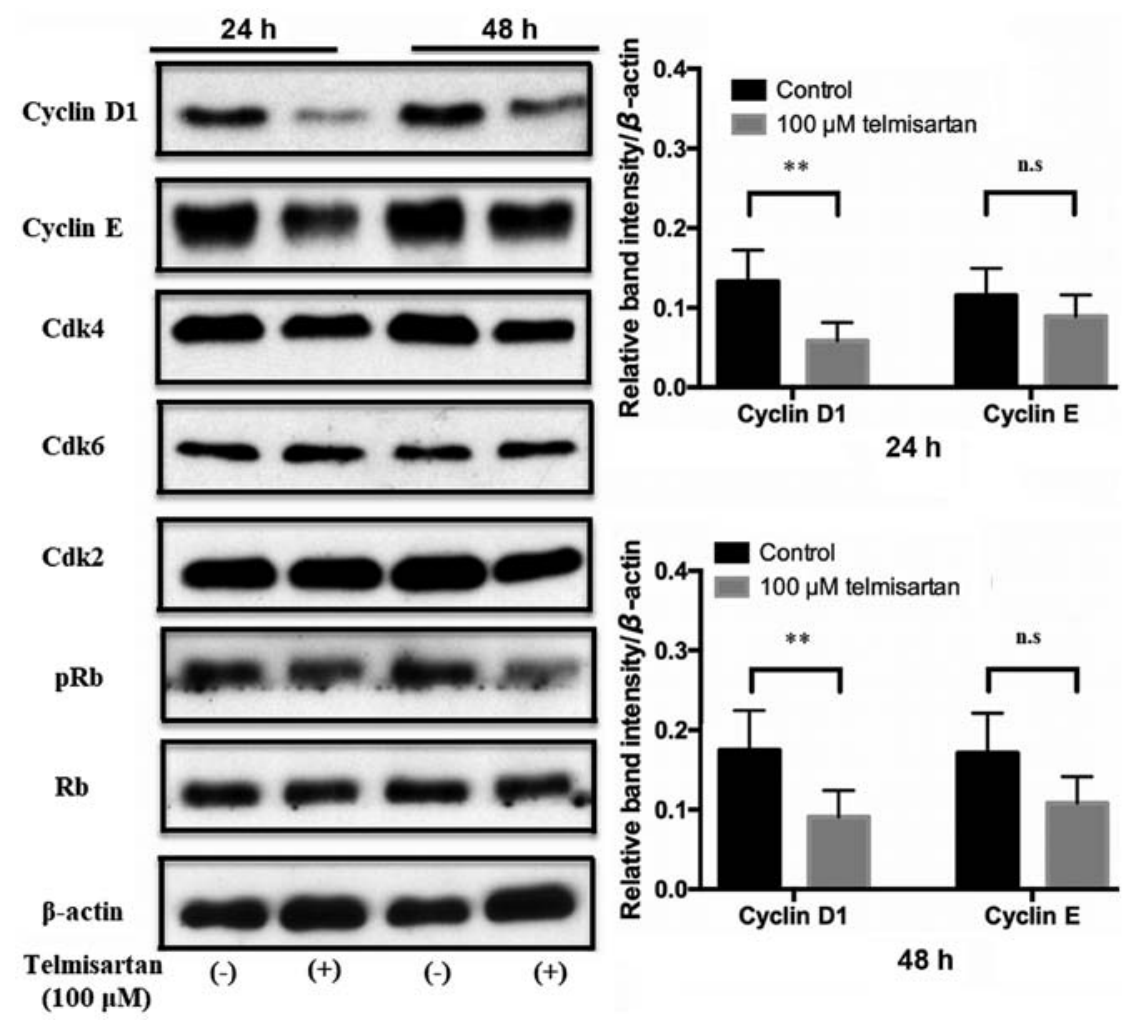

Figure 3. Representative western blotting images and densitometric analyses demonstrating the protein expression levels of cyclin D1, Cdk4, Cdk6, cyclin E, $\mathrm{Cdk} 2$ and $\mathrm{p}-\mathrm{Rb}$ in GIST-T1 cells at 24 and $48 \mathrm{~h}$ after addition of $100 \mu \mathrm{m}$ telmisartan. The images are representative of three independent experiments, and protein levels were normalized to $\beta$-actin. Values represent mean $\pm \mathrm{SD} ;{ }^{* *} \mathrm{P}<0.01$. n.s., not significant; $\mathrm{p}$, phosphorylated.

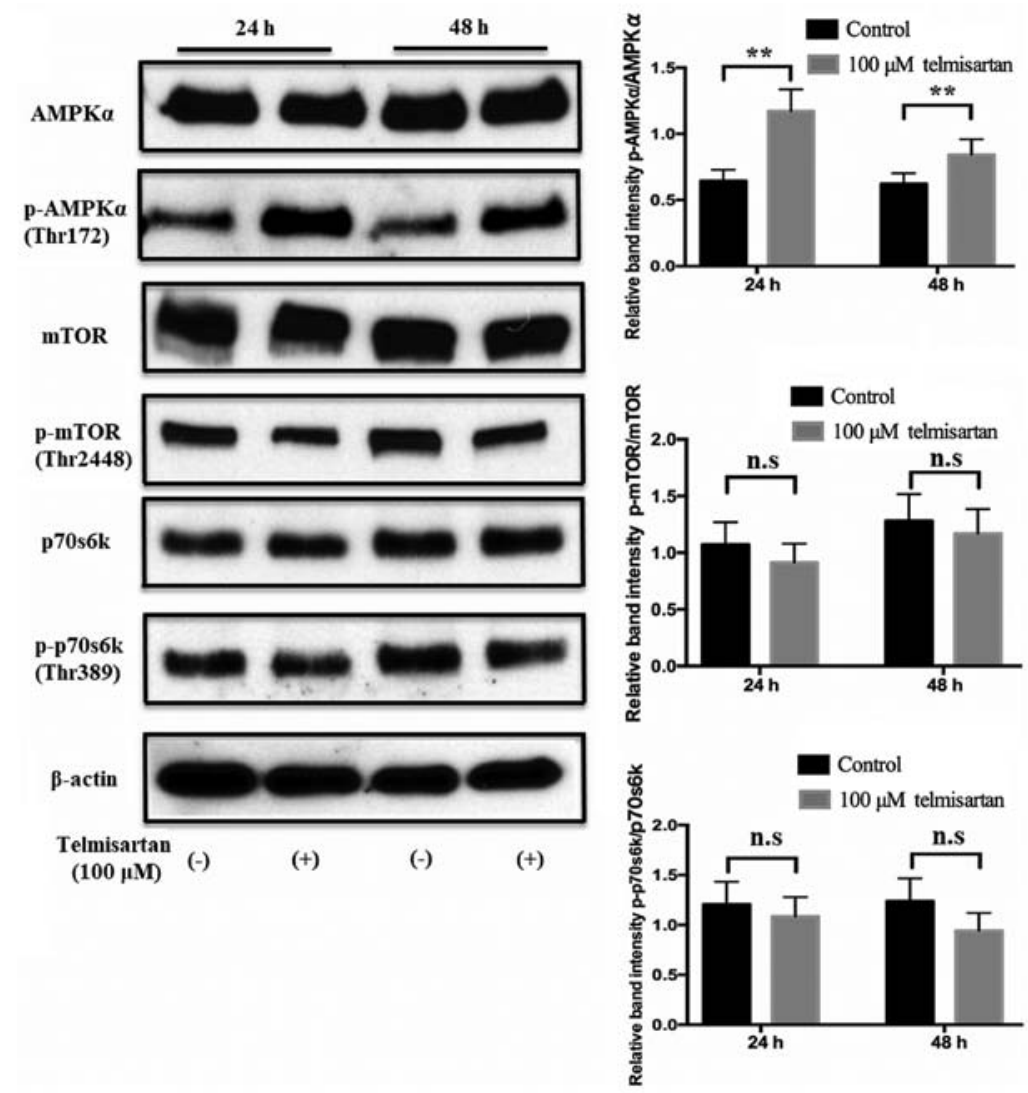

Figure 4. Representative western blotting images and densitometric analyses demonstrating the protein expression levels of AMPK, p-AMPK $\alpha$, mTOR, p-mTOR, p70s6k and p-p70s6k. Telmisartan induced AMPK phosphorylation but did not suppress the mTOR pathway in GIST-T1 cells. The images are representative of three independent experiments, and protein levels were normalized to $\beta$-actin. ${ }^{* *} \mathrm{P}<0.01$. Values represent mean $\pm \mathrm{SD}$. n.s., not significant; p-, phosphorylated; AMPK, AMP-activated protein kinase; GIST, gastrointestinal stromal tumor. 


\begin{tabular}{|c|c|c|c|c|c|c|c|c|c|c|c|}
\hline \begin{tabular}{|c|}
$\begin{array}{c}\text { Reference } \\
\text { spots }\end{array}$ \\
\end{tabular} & & Activin A & ADAMTS- 1 & Angiogenin & \begin{tabular}{|c|} 
Angiopoietin \\
-1 \\
\end{tabular} & \begin{tabular}{|c|} 
Angiopoietin \\
-2 \\
\end{tabular} & \begin{tabular}{l|} 
Angiostatin/ \\
Plasminogen
\end{tabular} & $\begin{array}{c}\text { Amphireguli } \\
\mathrm{n}\end{array}$ & Artemin & & $\begin{array}{c}\text { Reference } \\
\text { spots }\end{array}$ \\
\hline \begin{tabular}{|c|}
$\begin{array}{c}\text { Coagulation } \\
\text { Factor } 3\end{array}$ \\
\end{tabular} & CXCL16 & DPP 4 & EGF & EG-VEGF & Endoglin & $\begin{array}{c}\text { Endostatin/C } \\
\text { ollagen18 } \\
\end{array}$ & Endothelin-1 & FGF acidic & FGF basic & FGF-4 & FGF-7 \\
\hline GDNF & GM-CSF & HB-EGF & HGF & IGFBP-1 & IGFBP-2 & IGFBP-3 & IL- $1 \beta$ & IL-8 & \begin{tabular}{|c} 
LAP(TGF- \\
$\beta 1)$ \\
\end{tabular} & Leptin & MCP-1 \\
\hline MIP-1 $1 \alpha$ & MMP-8 & MMP-9 & NRG1- $\beta 1$ & $\begin{array}{c}\text { Pentraxin } 3 \\
\text { (PTX3) }\end{array}$ & PD-ECGF & PDGF-AA & \begin{tabular}{|c|} 
PDGF- \\
AB/PDGF- \\
BB
\end{tabular} & Persephin & $\begin{array}{c}\text { Platelet } \\
\text { Factor } 4 \\
\text { (PF4) }\end{array}$ & PIGF & Prolactin \\
\hline Serpin B5 & Serpin E1 & Serpin F1 & TIMP-1 & TIMP-4 & $\begin{array}{c}\text { Thrombospo } \\
\text { ndin-1 }\end{array}$ & \begin{tabular}{|c|}
$\begin{array}{c}\text { Thrombospo } \\
\text { ndin-2 }\end{array}$ \\
\end{tabular} & uPA & Vasohibin & VEGF & VEGF-C & \\
\hline $\begin{array}{c}\text { Reference } \\
\text { spots }\end{array}$ & & & & & & & & & & & $\begin{array}{c}\text { Negative } \\
\text { control }\end{array}$ \\
\hline
\end{tabular}

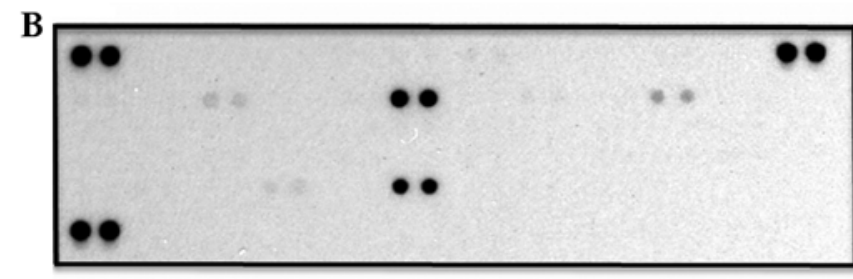

Telmisartan (-)

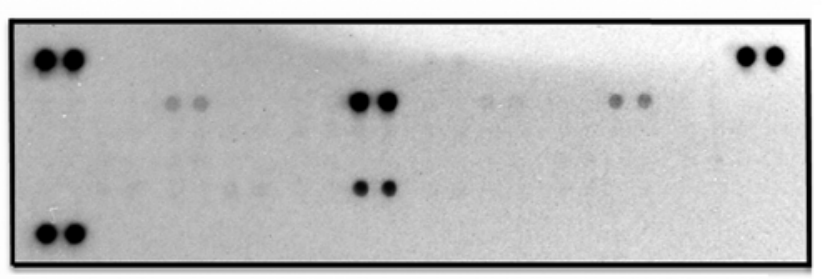

Telmisartan (+)

Figure 5. Effects of telmisartan on angiogenesis of GIST-T1 cells. (A) Angiogenesis array image of 55 angiogenesis-related cytokines. (B) Human-specific angiogenesis antibody array membranes were incubated with or without telmisartan in GIST-T1 cells. GIST, gastrointestinal stromal tumor.
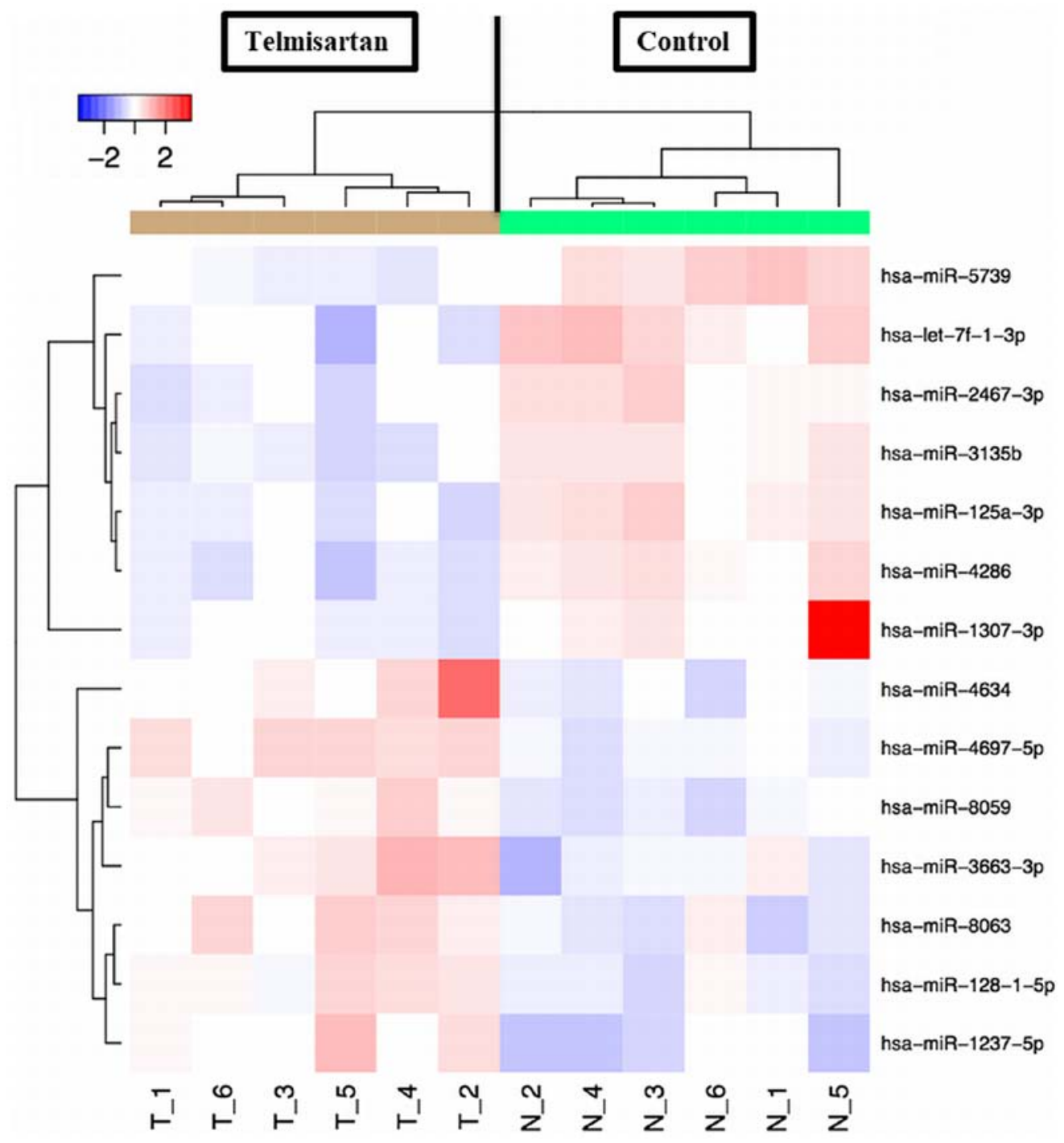

Figure 6. Hierarchical clustering of GIST-T1 cells cultured with or without telmisartan. The analyzed samples are shown in the columns, and the miRNAs are presented in the rows. The miRNA clustering color scale presented at the top indicates the relative miRNA expression levels with red and blue representing high and low expression levels, respectively. GIST, gastrointestinal stromal tumor; miRNA/miR, microRNA; T, telmisartan treated group; N, control group. 
Table I. Statistical results and chromosomal locations of miRNAs in GIST-T1 cells treated with and without telmisartan.

\begin{tabular}{lccc}
\hline A, Upregulated miRNAs & FC (treated/untreated) & P-value & Chromosomal location \\
hsa-miR-4634 & 2.03 & 0.0022 & $5 \mathrm{q} 35.2$ \\
hsa-miR-1237-5p & 1.79 & 0.0087 & $11 \mathrm{q} 13.1$ \\
hsa-miR-3663-3p & 1.70 & 0.0087 & $10 \mathrm{q} 25.3$ \\
hsa-miR-4697-5p & 1.65 & 0.0022 & $11 \mathrm{q} 25$ \\
hsa-miR-8063 & 1.63 & 0.0087 & $15 \mathrm{q} 14$ \\
hsa-miR-8059 & 1.57 & 0.0050 & $21 \mathrm{p} 12$ \\
hsa-miR-128-1-5p & 1.52 & 0.0087 & $2 \mathrm{q} 21.3$ \\
\end{tabular}

B, Downregulated miRNAs

FC (treated/untreated)

P-value

Chromosomal location

\begin{tabular}{lccc}
\hline hsa-miR-1307-3p & 0.28 & 0.0087 & $10 \mathrm{q} 24.33$ \\
hsa-let-7f-1-3p & 0.54 & 0.0043 & $9 \mathrm{q} 22.32$ \\
hsa-miR-5739 & 0.58 & 0.0022 & $22 \mathrm{q} 12.1$ \\
hsa-miR-4286 & 0.59 & 0.0050 & $8 \mathrm{p} 23.1$ \\
hsa-miR-3135b & 0.64 & 0.0050 & $6 \mathrm{p} 21.32$ \\
hsa-miR-125a-3p & 0.64 & 0.0087 & $19 \mathrm{q} 13.41$ \\
hsa-miR-2467-3p & 0.64 & 0.0050 & $2 \mathrm{q} 37.3$
\end{tabular}

FC, Fold change; miRNA, microRNA; GIST, gastrointestinal stromal tumor. Upregulated miRNAs with FC $>1.5$ and $\mathrm{P}<0.05$ are presented. Downregulated miRNAs with $\mathrm{FC}<0.68$ and $\mathrm{P}<0.05$ are presented.

different times during cell cycle progression (32). Cdk4 and Cdk6 form complexes with cyclin D1, which are required for G1 phase progression, whereas Cdk2 forms a complex with cyclin $\mathrm{E}$, which is required for the G1-S transition $(31,32)$. The expression of various cell cycle-related molecules has been associated with cancer cell metastasis and is related to cancer prognosis $(33,34)$. Previous studies have shown that telmisartan induces cell cycle arrest in G0/G1 phase by decreasing cyclin D1 and cyclin E $(22,23)$. Results from the present study indicated that telmisartan reduces the expression of cyclin D1 and induces cell cycle arrest in GIST-T1 cells.

Previous studies have shown that telmisartan inhibits cell proliferation by inducing apoptosis in various types of cancer, including gynecological $(12)$ and urological $(16,17)$ cancer cell lines. Furthermore, it has been demonstrated that telmisartan induces cell cycle progression, but not apoptosis in esophageal adenocarcinoma (22). In the present study, telmisartan did not increase the rates of apoptosis of GIST-T1 cells, as shown by flow cytometry, which suggested that telmisartan mainly inhibits GIST-T1 cell proliferation by inducing cell cycle arrest but not apoptosis.

Telmisartan has been shown to activate AMPK $\alpha$ in various cancer cells $(22,23)$. Previous studies have shown that telmisartan induces antiproliferative effects by phosphorylating AMPK $\alpha$ in esophageal adenocarcinoma cells, suggesting that AMPK $\alpha / m$ TOR pathway activation inhibits cell cycle regulatory proteins $(22,23)$. In the present study, proteins involved in the AMPK $\alpha / \mathrm{mTOR}$ signaling pathways, such as p-AMPK $\alpha$, p-mTOR and p-p70S6K, were evaluated. Telmisartan treatment led to phosphorylation of AMPK, but it did not inhibit p70S6K or mTOR phosphorylation in GIST-T1 cells, which suggested that telmisartan induced AMPK $\alpha$ signaling in GIST-T1 cells but did not affect downstream mTOR in GIST-T1 cells.

The tumor microenvironment is the product of crosstalk between different cell types and serves a critical role in promoting the initiation and progression of malignancy (35). Okazaki et al (13) reported that candesartan suppressed tumor growth and angiogenesis in a xenograft mouse model. Although telmisartan and candesartan are both known as ARBs, telmisartan is also a partial agonist of PPAR- $\gamma$ (7). However, in the present study, the 55 screened angiogenesis-related molecules had no changes after treatment with telmisartan in GIST-T1 cells. Thus, it was speculated that PPAR- $\gamma$ does not play a major role in angiogenesis of GIST-T1 cells.

miRNAs are endogenous mediators of gene expression through site-specific binding at the 3'untranslated region of target mRNAs leading to degradation or inactivate protein synthesis (36). miRNAs regulate a number of biological processes, such as cancer cell proliferation, tumor growth, differentiation, apoptosis and energy metabolism (37). miR-1307-3p was downregulated in GIST-T1 cells treated with telmisartan. miR-1307-3p originates from the 3'end of pre-miR-1307, but its function remains largely unknown. It has been reported that miR-1307 is overexpressed in chemoresistant ovarian (38) and prostate cancer tissues (39). miR-1307 overexpression has been shown to inhibit levels of the cell cycle inhibitors, p21 and p27 in prostate cancer cells (39). Based on these studies and the present data, it is suggested that the antiproliferative effects of telmisartan may alter several miRNAs. However, there are some limitations to the current study. Firstly, the inhibition effects of telmisartan on GIST-T1 cells were optimized only for in vitro growth and proliferation. Secondary, the in vitro study was conducted using a higher 
dose of telmisartan than that used in human treatments $(1-10 \mu \mathrm{M})(7)$. Thus, it may be difficult to translate these conditions in clinical setting, especially as the pharmacokinetics of the drug may be different in a culture setting and in the human body.

In conclusion, it was demonstrated that telmisartan treatment inhibited human GIST cell proliferation, which may be by inducing cell cycle arrest and decreasing the expression of cyclin D1.

\section{Acknowledgements}

Not applicable.

\section{Funding}

The current study was supported by The Japan Society for the Promotion of Science (JSPS) KAKENHI (grant no. 18K11023).

\section{Availability of data and materials}

The datasets used and/or analyzed during the current study are available from the corresponding author on reasonable request.

\section{Authors' contributions}

HK, SF and TsM conceived and deigned the study. TaM, AF, TC, STT, NK, NN, TY, TT, KyO, JT, KF, TN, HY, AM, $\mathrm{KeO}$, YS and HM performed the experiments and were major contributors in writing the manuscript. HI interpreted the data and drafted the manuscript. All authors read and approved the final manuscript.

\section{Ethics approval and consent to participate}

Not applicable.

\section{Patient consent for publication}

Not applicable.

\section{Competing interests}

The authors declare that they have no competing interests.

\section{References}

1. Rubin BP, Heinrich MC and Corless CL: Gastrointestinal stromal tumor. Lancet 369: 1731-1741, 2007.

2. Giuliano K, Ejaz A, Reames BN, Choi W, Sham J, Gage M, Johnston FM and Ahuja N: Comparing the long-term outcomes among patients with stomach and small intestine gastrointestinal stromal tumors: An analysis of the National Cancer Database. J Surg Oncol 118: 486-492, 2018.

3. Corless CL, Fletcher JA and Heinrich MC: Biology of gastrointestinal stromal tumors. J Clin Oncol 22: 3813-3825, 2004.

4. Fletcher CD, Berman JJ, Corless C, Gorstein F, Lasota J, Longley BJ, Miettinen M, O'Leary TJ, Remotti H, Rubin BP, et al Diagnosis of gastrointestinal stromal tumors: A consensus approach. Hum Pathol 33: 459-465, 2002.

5. Miettinen Mand Lasota J: Gastrointestinal stromal tumors: Pathology and prognosis at different sites. Semin Diagn Pathol 23: 70-83, 2006.

6. Yamamoto $\mathrm{H}$ and Oda Y: Gastrointestinal stromal tumor: Recent advances in pathology and genetics. Pathol Int 65: 9-18, 2015.
7. Benson SC, Pershadsingh HA, Ho CI, Chittiboyina A, Desai P, Pravenec M, Qi N, Wang J, Avery MA and Kurtz TW: Identification of telmisartan as a unique angiotensin II receptor antagonist with selective PPAR-modulating activity. Hypertension 43: 993-1002, 2004.

8. Kinoshita J, Fushida S, Harada S, Yagi Y, Fujita H, Kinami S, Ninomiya I, Fujimura T, Kayahara M, Yashiro M, et al: Local angiotensin II-generation in human gastric cancer: Correlation with tumor progression through the activation of ERK1/2, NF- $\mathrm{BB}$ and survivin. Int J Oncol 34: 1573-1582, 2009.

9. Okamoto K, Tajima H, Ohta T, Nakanuma S, Hayashi H, Nakagawara H, Onishi I, Takamura H, Ninomiya I, Kitagawa H, et al: Angiotensin II induces tumor progression and fibrosis in intrahepatic cholangiocarcinoma through an interaction with hepatic stellate cells. Int J Oncol 37: 1251-1259, 2010.

10. Du N, Feng J, Hu LJ, Sun X, Sun HB, Zhao Y, Yang YP and Ren H: Angiotensin II receptor type 1 blockers suppress the cell proliferation effects of angiotensin II in breast cancer cells by inhibiting AT1R signaling. Oncology Rep 27: 1893, 2012.

11. Chen X, Meng Q, Zhao Y, Liu M, Li D, Yang Y, Sun L, Sui G, Cai $L$ and Dong $X$ : Angiotensin II type 1 receptor antagonists inhibit cell proliferation and angiogenesis in breast cancer. Cancer Lett 328: 318-324, 2013.

12. Koyama N, Nishida Y, Ishii T, Yoshida T, Furukawa Y and Narahara H: Telmisartan induces growth inhibition, DNA double-strand breaks and apoptosis in human endometrial cancer cells. PLoS One 9: e93050, 2014

13. Okazaki M,Fushida S, Harada S, Tsukada T, Kinoshita J, Oyama K, Tajima H, Ninomiya I, Fujimura T and Ohta T: The angiotensin II type 1 receptor blocker candesartan suppresses proliferation and fibrosis in gastric cancer. Cancer Lett 355: 46-53, 2014.

14. Bhaskaran K, Douglas I, Evans S, van Staa T and Smeeth L: Angiotensin receptor blockers and risk of cancer: Cohort study among people receiving antihypertensive drugs in UK general practice research database. BMJ 344: e2697, 2012.

15. Makar GA, Holmes JH and Yang YX: Angiotensin-converting enzyme inhibitor therapy and colorectal cancer risk. J Natl Cancer Inst 106: djt374, 2014.

16. Funao K, Matsuyama M, Kawahito Y, Sano H, Chargui J, Touraine JL, Nakatani T and Yoshimura R: Telmisartan is a potent target for prevention and treatment in human prostate cancer. Oncol Rep 20: 295-300, 2008.

17. Funao K, Matsuyama M, Kawahito Y, Sano H, Chargui J, Touraine JL, Nakatani T and Yoshimura R: Telmisartan as a peroxisome proliferator-activated receptor-gamma ligand is a new target in the treatment of human renal cell carcinoma. Mol Med Rep 2: 193-198, 2009.

18. Lee L, Mafura B, Lauscher J, Seeliger H, Kreis M and Gröne J: Antiproliferative and apoptotic effects of telmisartan in human colon cancer cells. Oncol Lett 8: 2681-2866, 2014.

19. Rehman G, Shehzad A, Khan AL and Hamayun M: Role of AMP-activated protein kinase in cancer therapy. Arch Pharm (Weinheim) 347: 457-468, 2014.

20. Dann SG and Thomas G: The amino acid sensitive TOR pathway from yeast to mammals. FEBS Lett 580: 2821-2829, 2006.

21. Fingar DC and Blenis J: Target of rapamycin (TOR): An integrator of nutrient and growth factor signals and coordinator of cell growth and cell cycle progression. Oncogene 23: 3151-3171, 2004.

22. Fujihara S, Asahiro M, Ogawa K, Tadokoro T, Chiyo T, Kato K, Kobara $\mathrm{H}$, Mori $\mathrm{H}$, Iwama $\mathrm{H}$ and Masaki $\mathrm{T}$ : The angiotensin II type 1 receptor antagonist telmisartan inhibits cell proliferation and tumor growth of esophageal adenocarcinoma via the AMPK $\alpha / \mathrm{mTOR}$ pathway in vitro and in vivo. Oncotarget 8 : 8536-8549, 2017.

23. Oura K, Tadokoro T, Fujihara S, Morishita A, Chiyo T, Samukawa E, Yamana Y, Fujita K, Sakamoto T, Nomura T, et al: Telmisartan inhibits hepatocellular carcinoma cell proliferation in vitro by inducing cell cycle arrest. Oncol Rep 38: 2825-2835, 2017.

24. Liang $\mathrm{LH}$ and $\mathrm{He} \mathrm{XH}$ : Macro-management of microRNAs in cell cycle progression of tumor cells and its implications in anti-cancer therapy. Acta Pharmacol Sin 32: 1311-1320, 2011.

25. Laemmli UK: Cleavage of structural proteins during the assembly of the head of bacteriophage T4. Nature 227: 680-685, 1970

26. Towbin H, Staehelin T and Gordon J: Electrophoretic transfer of proteins from polyacrylamide gels to nitrocellulose sheets: Procedure and some applications. Proc Natl Acad Sci USA 76: 4350-4354, 1979.

27. Benjamini Y and Hochberg Y: Controlling the false discovery rate: A practical and powerful approach to multiple testing. J Roy Stat Soc 57: 289-300, 1995. 
28. de Araújo Júnior RF, Leitão Oliveira AL, de Melo Silveira RF, de Oliveira Rocha HA, de França Cavalcanti P and de Araújo AA: Telmisartan induces apoptosis and regulates Bcl-2 in human renal cancer cells. Exp Biol Med (Maywood) 240: 34-44, 2015.

29. Sipahi I, Debanne SM, Rowland DY, Simon DI and Fang JC: Angiotensin-receptor blockade and risk of cancer: Meta-analysis of randomised controlled trials. Lancet Oncol 11: 627-636, 2010

30. Shen J, Huang YM, Wang M, Hong XZ, Song XN, Zou X, Pan YH, Ling W, Zhu MH, Zhang XX, et al: Renin-angiotensin system blockade for the risk of cancer and death. J Renin Angiotensin Aldosterone Syst 17: pii: 1470320316656679, 2016.

31. Masaki T, Shiratori Y, Rengifo W, Igarashi K, Yamagata M, Kurokohchi K, Uchida N, Miyauchi Y, Yoshiji H, Watanabe S, et al: Cyclins and cyclin-dependent kinases: Comparative study of hepatocellular carcinoma versus cirrhosis. Hepatology 37: 534-543, 2003.

32. Kato K, Gong J, Iwama H, Kitanaka A, Tani J, Miyoshi H, Nomura K, Mimura S, Kobayashi M, Aritomo Y, et al: The antidiabetic drug metformin inhibits gastric cancer cell proliferation in vitro and in vivo. Mol Cancer Ther 11: 549-560, 2012.
33. Itami A, Shimada Y, Watanabe G and Imamura M: Prognostic value of p27 ${ }^{\text {Kipl }}$ and cyclin D1 expression in esophageal cancer. Oncology 57: 311-317, 1999.

34. Fukuchi M, Fukai Y, Kimura H, Sohda M, Miyazaki T, Nakajima M, Masuda N, Tsukada K, Kato H and Kuwano H: Prolyl isomerase Pinl expression predicts prognosis in patients with esophageal squamous cell carcinoma and correlates with cyclinD1 expression. Int J Oncol 29: 329-334, 2006.

35. Samples J, Willis M and Klauber-DeMore N: Targeting angiogenesis and the tumor microenvironment. Surg Oncol Clin N Am 22: 629-639, 2013

36. Masaki T: MicroRNA and hepatocellular carcinoma. Hepatol Res 39: 751-752, 2009.

37. Morishita A and Masaki T: miRNA in hepatocellular carcinoma. Hepatology Res 45: 128-141, 2015.

38. Zhou Y, Wang M, Wu J, Jie Z, Chang S and Shuang T: The clinicopathological significance of miR-1307 in chemotherapy resistant epithelial ovarian cancer. J Ovarian Res 8: 23, 2015.

39. Qiu X and Dou Y: miR-1307 promotes the proliferation of prostate cancer by targeting FOXO3A. Biomed Pharmacother 88 : 430-435, 2017. 